\title{
TERAPI SPIRITUAL MELALUI KAEDAH TAZKIYAH AL-NAFS OLEH SYEIKH ABDUL QADIR AL-MANDILI DALAM KITAB PENAWAR BAGI HATI
}

SPIRITUAL THERAPY USING THE METHOD OF TAZKIYAH AL-NAFS BY SYEIKH ABDUL QADIR ALMANDILI BASED ON KITAB PENAWAR BAGI HATI

Che Zarrina Sa'ari", Nor Azlinah Zaini**

Akademi Pengajian Islam. Universiti Malaya. 50603. Kuala Lumpur. Malaysia.

Emel: azlinah@uum.edu.my

\begin{abstract}
Khulasah
Konsep penyucian hati (tazkiyah al-nafs) yang disebut juga sebagai tazkiyah al-qalb, merupakan intipati penting dalam perbincangan Kitab Penawar Bagi Hati yang disusun oleh Syeikh Abdul Qadir alMandili. Beliau mengemukakan konsep-konsep penyucian hati dalam tiga komponen utama iaitu pertama kawalan dan pencegahan kerosakan tujuh anggota yang zahir, kedua rawatan dan rehabilitasi sifat-sifat yang dicela (mazmumah), dan terakhir suntikan penerapan sifat-sifat yang dipuji (mahmudah). Makalah ini akan memperkenalkan kaedah tazkiyah al-nafs yang telah digarap secara sempurna oleh Syeikh Abdul Qadir al-Mandili sebagai penyelesaian penyakit yang berpunca daripada hati.
\end{abstract}

Kata kunci: Terapi spiritual, tazkiyah al-nafs, Abdul Qadir al-Mandili, Kitab Penawar Bagi Hati

\begin{abstract}
The concept of soul purification (tazkiyah al-nafs), which is also known as tazkiyah al-qalb is an essential ingredient in the discussion of the Kitab Penawar Bagi Hati compiled by Syeikh Abdul Qadir al-Mandili. He put forward the concepts of soul
\end{abstract}


purification into three main components, which begins with method of controling and preventing the damage of seven human physical, second methods is the treatment and rehabilitation from negative attitudes (mazmumah), whereas the last methods by injection applying positive values (mahmudah). This paper will introduce methods tazkiyah al-nafs that has worked perfectly by Syeikh Abdul Qadir alMandili as a solution stemming from soul disease.

Keywords: Spiritual therapy, tazkiyah al-nafs, Abdul Qadir al-Mandili, Kitab Penawar Bagi Hati

\section{Pendahuluan}

Perluasan ilmu dan kesarjanaan Islam telah merentasi blok negara dan merentasi batasan kaum sehingga tidak meninggalkan alam Nusantara ini tanpa kehadiran ulama yang memainkan peranan menabur usaha dan bakti kepada masyarakat dalam pelbagai kepakaran, pemikiran, politik dan kemasyarakatan ${ }^{1}$. Keunikan sejarah kegiatan para ulama Semenanjung Tanah Melayu pula dapat dilihat melalui beberapa kategori berbeza. Kebanyakkan alim ulama ini terlibat secara khusus dan langsung dalam kegiatan penyebaran dan pengajaran ilmu pengetahuan kepada masyarakat awam mahupun khusus kepada para pelajarnya. Sebahagian lain pula meningkatkan inovasi dengan menghasilkan karya melalui penulisan kitab mahupun risalah. Manakala terdapat segelintir ulama melepasi garisan kebiasaan ini dengan melibatkan diri

1 Lihat Mohamad Abu Bakar, "Tanah Melayu Abad ke-19: Pengislaman, Penjajahan dan Pemupukan Manhaj Melayu", dalam Islam di Tanah Melayu Abad ke-19, ed. Farid Mat Zain (Shah Alam: Karisma Publications Sdn. Bhd, 2007), 1-2. Lihat juga Shukri Ahmad, Pengaruh Pemikiran Ulama di Semenanjung Malaysia Akhir Abad ke-20 (Sintok: Penerbit Universiti Utara Malaysia Sintok, 2011), 9-11. 
dalam kegiatan masyarakat semasa seperti terlibat dengan politik negara ${ }^{2}$.

Al-Mandili telah merepresentasikan peranan dan figura peribadi yang bervariasi merentasi sempadan negara, bangsa dan sumbangan melalui dunia keilmuan dan peranan beliau dalam merawat penyakit masyarakat semasa. Sumbangan pemikiran beliau yang telah dicatatkan dalam penulisannya masih dapat dimanfaatkan buat pedoman masyarakat hari ini.

\section{Biodata Syeikh Abdul Qadir al-Mandili}

Tokoh Mandailing yang dibicarakan ini ialah Syeikh 'Abd al-Qādīr bin Abd Al-Mutallib Al-Mandīlì. Menilik kepada latar belakang awal al-Mandili, tidak banyak maklumat rasmi yang direkodkan berkenaan tarikh dan tempat kelahiran beliau. Nama tokoh ini ialah Abdul Qadir bin Abd al-Muțalib ${ }^{3}$ bin Hassan ${ }^{4}$. Beliau merupakan anak kelahiran Desa Sigalapang ${ }^{5}$ di Daerah Penyabungan Kabupaten Mandailing Natal Sumatera Utara Indonesia,

2 Abdul Razak Mahmud, "Haji Husain Che Dol (1904-1967)," dalam Tokoh-tokoh Ulama' Semenanjung Melayu (2), ed. Ismail Che Daud (Kota Bharu: Majlis Agama Islam dan Adat Istiadat Melayu Kelantan, 2007), 83.

${ }^{3}$ Nama ini sering digunakan oleh al-Mandili dalam kebanyakan kitab tulisan beliau. Antaranya boleh dirujuk 'Abd Qādīr bin 'Abd. alMuțallib al-Indūnisī al-Mandīi, Penawar Bagi Hati (Thailand : Maṭba'ah Bin Hālabī, t.t), kulit hadapan.

${ }^{4}$ Ishamuddin Abd. Rahim, "Tokoh Ulamak al-Syeikh Abd al-Qadir alMandili: Tinjauan Pemikirannya dari Aspek Politik", (Latihan Ilmiah Sarjana Muda Pengajian Islam, Universiti Kebangsaan Malaysia, 1987), 1.

5 Syeikh Muhammad Husni Ginting (Mudir Pesantrean Husniyyah, Langkat) dalam temubual dengan pengkaji pada 20 November 2013. Beliau mendapatkan maklumat tempat kelahiran al-Mandili daripada guru beliau, Syeikh Ibrahim Zannun. Maklumat ini agak berbeza dengan pendapat Ishamuddin Abd. Rahim dan Ramli Awang yang mengatakan kelahiran al-Mandili di Kampung Sigalangam, Padang Sidingpuan. 
yang terletak di wilayah Tapanuli Selatan ${ }^{6}$, Sumatera Utara $^{7}$, Indonesia. Al-Mandili lahir pada tahun $1910 \mathrm{M}^{8}$ bersamaan 1329 Hijriyyah ${ }^{9}$. Beliau lahir dalam lingkungan masyarakat petani dan mendapat pendidikan asas di daerah kelahirannya seperti kebanyakan kanakkanak yang lain.

Nama gelaran beliau yang tercatat pada kitab-kitab tulisannya adakalanya berbeza-beza. Terdapat beberapa nisbah panggilan yang digunakan seperti al-Indūnisi $\bar{i}$ al-

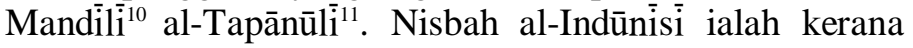
beliau dilahirkan di Indonesia. Penggunaan nisbah negara ini merupakan perkara biasa bagi memperkenalkan seorang tokoh atau pengarang tentang negara kelahirannya. Nisbah al-Mandili ini diambil daripada perkataan Mandailing, iaitu nama salah satu suku kaum atau bangsa Batak yang mendiami kawasan Sumatera Utara, Indonesia. Beliau juga dinisbahkan dengan alTapānūli iaitu tempat kelahiran beliau yang merupakan

${ }^{6}$ Di pergunungan sebelah Sumatera Timur tinggal dua kelompok sub etnik Batak, kelompok etnik Toba di Tapanuli Utara dan Mandailing di Tapanuli Selatan. Kedua-duanya berada dalam Wilayah Sumatera Utara dan ibu kotanya adalah Medan. Lihat Usman Pelly, Urbanisasi dan Adaptasi Peranan Misi Budaya Minangkabau dan Mandailing, Edited by Taufik Abdullah (Jakarta: LP3ES, 1994), 6.

${ }^{7}$ Lihat Ramli Awang, Syeikh Abdul Qadir al-Mandili (1910-1965) : Biografi \& Pendidikan Akhlak, (Skudai : Penerbit Universiti Teknologi Malaysia, 2008), 6.

${ }^{8}$ Sila lihat Ishamuddin Abd. Rahim, "Tokoh Ulamak al-Syeikh 'Abd al-Qadir al-Mandili”, 1. Lihat juga Ramli Awang, Syeikh Abdul Qadir Al-Mandili (1910-1965), 7.

${ }^{9}$ Lihat Muhammad Husni Ginting, Ibid.

${ }^{10}$ Nama ini dipetik sebagaimana dicatat dalam kitab-kitab karangan beliau seperti Kitab Penawar Bagi Hati.

11 Tapanuli nisbah kepada tempat iaitu salah sebuah daripada sepuluh kabupaten dalam wilayah Sumatera Utara. Nama gelaran ini disebut oleh Syeikh Abdul Qadir al-Mandili dalam kitab "Pembantu Sekalian Orang Islam dengan Harus Membaca Qur'an dan Sampai Pahalanya Pada Sekalian Yang Mati”, (Pulau Pinang : The United Press, 1962), 47. 
salah sebuah wilayah di Sumatera Utara itu. Oleh itu, nama penuh beliau berserta nisbah panggilan boleh disebut dengan Syeikh Abdul Qadir bin Abd al-Mutalib al-Indūnisisi al-Tapānūli al-Mandîli.

Al-Mandili dikatakan datang ke Tanah Melayu bersama dua orang lagi sahabatnya bernama Abdullah dan Haji Abbas untuk mencari tempat pengajian ${ }^{12}$. Mereka singgah dari satu pondok ke pondok yang lain mencari tempat pengajian yang sesuai. Al-Mandili telah menuntut ilmu di tiga buah pondok pengajian di Kedah. Pondok pertama tempat beliau menimba ilmu ialah Pondok Panjang Rong, Tobiar di Pendang, Kedah. Al-Mandili telah mempelajari asas-asas ilmu termasuk penguasaan membaca dan menulis jawi serta bahasa Arab dengan Tuan Guru Haji Bakar ${ }^{13}$. Al-Mandili kemudian berpindah ke Pondok Air Hitam, Kedah yang diterajui oleh Tuan Guru Haji Idris bin Lebai Yusuf. Di sini beliau mula belajar kitab-kitab Arab antaranya pengajian ilmu-ilmu alat seperti Matan al-Ajrūmiyyah, Muțammīmah dan matan Alfïyah Ibn Mālik daripada Lebai Dukun, iaitu ketua metela'ah pondok tersebut ${ }^{14}$.

Selepas menguasai ilmu-ilmu tersebut, al-Mandili berpindah pula ke Pondok Gajah Mati, Pendang. Pondok

12 Temubual dengan Tuan Guru Abd. Raof al-Bahanji, (Mudir Pondok Tampin) bersama pengkaji pada 21 November 2013. Beliau turut mencatatkan pengalaman beliau sendiri bertemu dengan Paksu Lah yang menyampaikan sumber maklumat ini. Petikan kata Tuan Guru Abdul Raof: "saya menziarahi sorang guru tua. Umurnya dekat 100 tahun. Orang memanggil beliau dengan gelaran Pak Su Lah. Beliau salah sorang dari tiga sahabat Syeikh Abd. Qoder al Mendeli yang datang musafir ke Tanah Melayu dengan tujuan menuntut ilmu. Seorang lagi bernama haji Abbas, guru juga."

${ }^{13}$ Lihat Ishamuddin Abd. Rahim, "Tokoh Ulamak al-Syeikh Abd alQadir al-Mandili", 4; dan Ramli Awang, Syeikh Abdul Qadir AlMandili (1910-1965), 10.

${ }^{14}$ Ibid. 
ini diasaskan oleh tuan guru Haji Ismail Cik Dol ${ }^{15}$, namun begitu ia diambil alih oleh menantunya Tuan Guru Haji Wan Ibrahim Bin Haji Wan Abdul Qadir (1894-1968M) yang lebih dikenali dengan nama Pak $\mathrm{Cu}$ Him. Beliau adalah seorang ulama berasal daripada Patani dari keluarga Tok Bendang Daya ${ }^{16}$. Al-Mandili menuntut ilmu selama lebih kurang sepuluh tahun di Pondok Gajah Mati ini bersama Pak $\mathrm{Cu}$ Him dan beliau turut diberikan amanah untuk mengajar di pondok ini. Pondok Gajah Mati pula pada ketika itu merupakan kemuncak zaman kegemilangannya kerana penuntut ilmu yang ada hampir mencecah lima ratus ke enam ratus orang murid yang datang bukan sahaja dari Semenanjung Tanah Melayu, tetapi juga dari Patani, Thailand dan Indonesia termasuk Kepulauan Sumatera ${ }^{17}$ iaitu dipercayai penuntut-penuntut dari kalangan warga Mandailing ${ }^{18}$.

Pada tahun $1355 \mathrm{H}$, al-Mandili berangkat menuju Mekah al-Mukarramah untuk menunaikan haji. Setelah menunaikan fardu haji, beliau berniat untuk bermukim di Mekah agar dapat belajar dengan ulama-ulama besar yang berada di sana. Walaupun al-Mandili telah menguasai banyak pengetahuan agama dan hafalan matan-matan ilmu semasa pengajian beliau di Kedah, namun semasa di Mekah beliau tidak mahu melepaskan peluang mendalami

${ }^{15}$ Nama penuh beliau ialah Haji Wan Ismail bin Wan Mustafa bin Wan Musa al-Samlawi (1873-1948M). Lihat Ahmad Fathi Al-Patani, Ulama Besar Dari Patani, Edisi Rumi (Bangi: Penerbit UKM, 2002), 274.

16 Tok Bendang Daya adalah gelaran kepada seorang ulama Patani yang sangat terkenal pada separuh kedua abad ke 19. Gelaran ini diberi kerana beliau menjadi Syeikh di Pondok Bendang Daya yang diasaskan oleh ayahnya. Nama beliau ialah Syeikh Wan 'Abd alQādīr bin Wan Mustapha (1895M). Beliau adalah bapa kepada Pak Cu Him. Ibid., 225.

17 Temubual dengan En. Mahfor bin Hj. Hassan, (cucu kepada Tuan Guru Ismail Che' Dol) pada 6 Oktober 2012 di Kampung Batu Hampar, Pendang Kedah.

${ }^{18}$ Lihat Ahmad Fathi Al-Patani, Ulama Besar Dari Patani, 285. 
lebih banyak ilmu. Beliau bersungguh-sungguh mendampingi ramai para ulama dan mempelajari pelbagai disiplin ilmu seperti tauhid, fikah, tasawuf, tafsir, hadith dan sebagainya ${ }^{19}$. Justeru, al-Mandili mampu menguasai pelbagai disiplin ilmu secara tahqiq (mendalam) dalam masa yang singkat ${ }^{20}$.

Antara guru-guru yang mencurahkan ilmu kepada alMandili di Kota Mekah ialah Tuan Guru Wan Ismail bin Wan Abdul-Qadir bin Wan Mustafa al-Fatani ${ }^{21}$ atau lebih dikenali sebagai Pak Da'el, Syeikh al-Kabïr al-Sayyīd

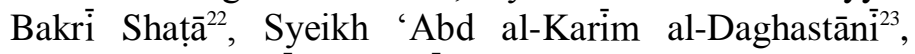
Syeikh Hasan Sa īd Yamānīi ${ }^{24}$, Syeikh Muhammad Nūr bin $\mathrm{Sayf}^{25}$, Syeikh Muhammad al-'Arabi bin al-Tabani bin alHussin al-Wāhidī al-Maghribī ${ }^{26}$, Syeikh al-Sayyid 'Alawi

19 Tuan Guru Haji Salleh bin Musa (Mudir Madrasah Rahmaniah, Sik,Kedah) dalam temubual bersama pengkaji, 19 Jun 2013.

${ }^{20}$ Tuan Guru Khairul Anwar, (Mudir Pondok Darul Muhajirin, Gajah Teriak) dalam temubual bersama pengkaji, 8 September 2012.

21 Beliau ialah abang kepada Pak $\mathrm{Cu}$ Him iaitu guru Syeikh Abdul Qadir al-Mandili semasa di Pondok Gajah Mati. Setelah ayahnya membawa beliau dan adiknya Pak $\mathrm{Cu}$ Him ke Mekah, beliau terus menetap di sana menuntut ilmu dan akhirnya menjadi seorang tokoh ulama besar Melayu di Mekah. Semasa di Mekah juga beliau mengajar dan telah melahirkan pula sejumlah murid, lebih dari 50 orang yang menjadi ulama-ulama ternama khususnya di Tanah Melayu. Lihat Ahmad Fathi Al-Fatani, Ulama' Besar Daripada Pattani, 167-178.

22 'Abd al-Qādīr Al-Mandīlī, Al-Khazā'in al-Sanīyyah min Mashāhir al-Kutub al-Fiqhìyah li A'immatinā al-Fuqahā' al-Shāfi'iyyah (Kaherah: Dār Miṣr li Ṭibā'ah, t.t), halaman mukadimah.

${ }^{23}$ Ibid.

24 Al-Mandili menyebutkan secara jelas nama gurunya ini di dalam kitab Siyasah dan Loteri serta 'Alim Ulama', (Mesir: Mațba'ah alAnwār, 1962), 43.

25 Ibid.

${ }^{26}$ Ibid. Juga disebut oleh al-Mandīli, Pembantu Sekalian Orang Islam dengan Harus Membaca Qur'an dan Sampai Pahalanya kepada Sekalian yang Mati, (Pulau Pinang: The United Press, Penang, 1962), 6. 


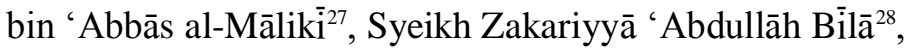
Syeikh Hassan Muhammad al-Mashātẹ", Syeikh Muhammad Yāsīn 'Īsā al-Fādānīi ${ }^{30}$, Syeikh 'Abdullāh Bahji ${ }^{31}$, Syeikh Muḥammad Ahyād bin Muhammad Idris ${ }^{32}$, Tuan Guru Hussin Abdul Ghani al-Falimbani ${ }^{33}$, Syeikh 'Abdul Rahim al-Kalantani ${ }^{34}$ dan terakhir Syeikh Daud alKalantani ${ }^{35}$.

Al-Mandili kemudiannya diamanahkan oleh kerajaan Arab Saudi untuk mengajar di satu sudut di kawasan Masjid al-Haram atas kepercayaan dan ketulenan ilmu yang ada pada beliau. Pengajian al-Mandili dihadiri oleh masyarakat Nusantara terdiri daripada kalangan warga Tanah Melayu, Indonesia dan Patani, Thailand. Para tetamu Allah yang datang ke Mekah untuk mengerjakan haji juga tidak ketinggalan mengikuti pengajian halaqah beliau pada masa tibanya musim haji.

Syeikh Abdul Qadir al-Mandili telah menghembuskan nafasnya yang terakhir pada pagi hari Selasa, 20 Rabiulakhir $1385 \mathrm{H}$ bersamaan 17 Ogos $1965 \mathrm{M}^{36}$ di Mekah al-Mukarrramah pada usia 55 tahun,

${ }^{27}$ Ibid.

${ }^{28}$ Ibid.

29 Ibid. Al-Mandili turut memperakukan bahawa Syeikh Hassan Muhammad Al-Masyāṭ adalah gurunya di dalam Kitab Larangan Memasukkan Anak-anak Orang Islam ke dalam Sekolah Orangorang Kafir (Mesir: Mațba'ah al-Anwār, 1961), 2.

${ }^{30}$ Ibid. Lihat juga 'Abd al-Qādīr Al-Mandīli, Senjata Tok Haji dan Tok Lebai , (Pattani: Mațba'ah Bin Halabì, Thailand, t.t), 68.

${ }^{31}$ Ibid.

${ }^{32}$ Lihat 'Abd al-Qādīr Al-Mandīlì, Senjata Tok Haji dan Tok Lebai (Thailand: Matba'ah Bin Hālabì, t.t) 68. Lihat juga 'Abd al-Qādīr alMandīi, Beberapa Mutiara yang Bagus Lagi Indah atau Beberapa Masalah yang Penting Lagi Mudah, (Mesir: Mațba'ah al-Anwār, 1960), 58-59.

33 'Abd al-Qādīr Al-Mandīì, Senjata Tok Haji dan Tok Lebai, 70.

${ }^{34}$ Ibid.

${ }^{35}$ Ibid.

${ }^{36}$ Sila rujuk catatan tarikh kematian al-Mandili yang diedarkan selepas kematian beliau. Nota ini diperolehi oleh Mohamed Bazri Che Harun 
setelah berkhidmat mengembangkan ilmu pengetahuan selama lebih 30 tahun. Al-Mandili telah dikebumikan di perkuburan Ma'la, Mekah dengan diiringi oleh ribuan manusia yang hadir memberikan penghormatan terakhir buat beliau.

\section{Pengenalan kepada Kitab Penawar Bagi Hati}

Al-Mandili sempat menghasilkan 24 karya yang diterbitkan dalam bentuk buku. Penulisan beliau terdiri daripada usaha penterjemahan, penyusunan dan tidak kurang karya autentik beliau sendiri. Salah satu karya yang disusun oleh al-Mandili adalah Kitab Penawar Bagi Hati. Kitab ini telah selesai ditulis pada 7 Rejab $1378 \mathrm{H}$ di Mekah bersamaan tahun $1958 \mathrm{M}^{37}$. Ianya telah diulang cetak beberapa kali di beberapa tempat pencetakan berbeza iaitu di Jala, Thailand, kedua di Pulau Pinang Malaysia dan ketiga di Patani, Thailand.

Kitab Penawar Bagi Hati merupakan sebuah kitab yang membicarakan beberapa perkara asas dalam permulaan pengajian ilmu tasawuf. Kitab ini membincangkan tentang pembentukan akhlak lahiriah daripada anggota tubuh badan serta perbincangan sifat terpuji dan tercela sebagai asas ilmu tasawuf yang mesti dipelajari dan diamalkan oleh setiap individu Muslim. Perbicaraan asas tasawuf dalam kitab ini bertujuan membersihkan hati daripada sepuluh sifat kekejian dan menghiasinya pula dengan sepuluh sifat kepujian. Justeru, untuk mencapai maksud tersebut, kitab ini memulakan perbicaraannya dengan tujuh anggota badan yang zahir

daripada Tuan Haji 'Abd al-Rahman al-Fatani, iaitu salah seorang anak murid Al-Mandili. Lihat Mohammed Bazri Che Harun, "Hadith-hadith dalam karya Syeikh 'Abd. al-Qadir al-Mandili: Takhrij Dan Analisis", (Disertasi Sarjana Usuluddin, Universiti Malaya, 2012), 56 dan 198.

37 Lihat 'Abd Qādīr bin 'Abd. al-Muțallib al-Indūnisì al-Mandīlí, Penawar Bagi Hati (Pattani: Mațba’ah Bin Hālabi, t.t), 100. 
iaitu mata, telinga, lidah, perut, kemaluan, dua tangan dan dua kaki.

Secara praktikalnya, kitab ini telah membincangkan tentang hubungan anggota badan yang zahir dengan amalan tasawuf. Ini kerana perbuatan anggota yang zahir ini akan mempengaruhi hati. Perbuatan dan tingkah laku buruk anggota zahir akan memberi kesan negatif kepada hati. Begitu pula apabila hati kotor dan penuh maksiat, maka akan melahirkan tingkah laku anggota zahir yang negatif. Apabila perbuatan anggota zahir melakukan kebaikan, ia akan menghasilkan hati yang suci. Ini bermakna, apabila hati yang bersih dan suci dari kotoran maksiat akan melahirkan tingkah laku anggota zahir yang baik.

Kitab Penawar Bagi Hati merupakan satu karya yang ditulis oleh Syeikh Abdul Qadir al-Mandili sebagai satu kompilasi karya-karya tasawuf berbentuk amali. Ianya muncul dalam situasi masyarakat yang sentiasa menempuh perubahan zaman yang mempunyai cabarannya tersendiri. Namun, tulisan al-Mandili yang terpandu daripada klausa dan tuntutan pemurnian akhlak bersumberkan daripada al-Qur'an dan hadith-hadith Nabi s.a.w merupakan suatu anugerah berharga sepanjang zaman.

Kitab ini menampilkan pengetahuan dan pemikiran al-Mandili dalam bidang pendidikan, akhlak dan tasawuf yang mendapat perhatian masyarakat sepanjang zaman ini. Pemikiran tasawuf al-Mandili ternyata mempunyai hubungan dengan tradisi tasawuf di kalangan ahli fiqh (fuqah $\bar{a}$ ') dan merupakan adunan daripada akidah dan hakikat dengan syariat. Oleh yang demikian, dalam kehidupan masyarakat hari ini yang telah banyak meninggalkan akhlak serta budi pekerti mulia, tidak beramal dengan sifat hati yang disuruh syarak, maka wajarlah kitab seperti ini ditampilkan dalam memberi 
kefahaman dan meningkatkan kesedaran untuk mempelajari pengajian fardu ain kepada masyarakat.

\section{Definisi Tazkiyah al-Nafs}

\section{Pengertian al-Tazkiyah dari Sudut Bahasa dan Istilah}

Penyucian (al-Tazkiyah) dalam bahasa Arab berasal

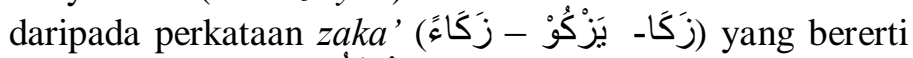

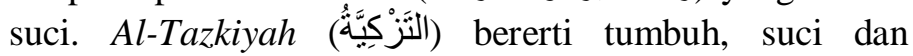
berkat $^{38}$. Contoh perkataan zakāt disebut sedemikian kerana ianya kembali kepada berkah, atau menyucikan jiwa, membersihkannya daripada sifat kikir (شخ atau keduanya $^{39}$. Zaka $\bar{a}$ terbentuk daripada dua kata benda yang merupakan gabungan antara yang dikeluarkan (مُخْرَجْ) dan

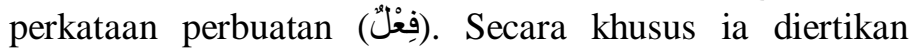
sebagai harta yang dibayarkan untuk zakat. Secara istilahnya membawa maksud penyucian ${ }^{40}$. Firman Allah SWT dalam surah al-Mukminun ayat 4 yang bermaksud: "dan mereka yang berusaha membersihkan hartanya (dengan menunaikan zakat harta itu)".

Zakāt dimaksudkan dengan dua pengertian iaitu menyucikan harta dan menyucikan jiwa ${ }^{41}$. Lawan perkataan ini adalah pengotoran jiwa (التدسية). Allah SWT menerangkan di dalam al-Qur'an:

Terjemahan: Sesungguhnya berjayalah orang yang menjadikan dirinya bertambah-tambah bersih (dengan iman dan amal kebajikan). Dan sesungguhnya hampalah orang yang menjadikan dirinya susut dan terbenam

38 Jamāl al-Dīn Ibn Muhammad Ibn Makram Ibn Manẓūr, Lisān al'Arab, jil. 16 (Beirut: Dār Șādir, t.t), 358.

39 Al-Husayn bin Muhammad ar-Rāghib al-Asfahani, Mufradāt fī Gharib al-Qur'ān (Beirut: Dār Ihyā’’ al-Turāth al-'Arabī, 2002), 213.

${ }^{40}$ Ibn Manzūur, Lisān al- 'Arab, jil. 16, 358.

${ }^{41}$ Ibn Kathïr, Tafsìr al-Qur'ān al- 'Ażìm, jil. 3, 238. 


\section{kebersihannya (dengan sebab kekotoran maksiat). ${ }^{42}$}

Terdapat sekurang-kurangnya enam ayat al-Qur'an

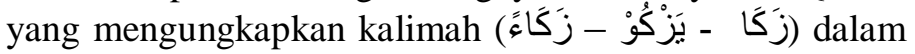
konteks makna yang hampir serupa tetapi tidak sama, namun saling berkaitan. Antara yang dapat disimpulkan daripadanya adalah ianya membawa pengertian sifat Allah SWT yang berhak menyucikan dan mengurniakan taufiq dan hidayah kepada manusia di dunia ${ }^{43}$, tugas Rasulullah s.a.w sebagai seorang yang mendidik dan menyucikan umatnya membawa ke jalan yang benar ${ }^{44}$, hamba yang berjaya menyucikan jiwanya ${ }^{45}$ serta menyucikan pemakanannya $^{46}$ dan terakhir makna yang membawa makna konsep penyucian manusia yang selalu memuji dirinya sendiri ${ }^{47}$.

Menepati maksud tazkiyah sebagai penyucian, pembersihan dan penyuburan diri serta penyingkiran segala bentuk perkembangan yang tidak dikehendaki dan segala perkara yang tidak baik $^{48}$, maksudnya diperkembangan kepada satu simpulan pengertian yang lebih spesifik. Sebagai suatu terma spiritual, tazkiyah mengandungi makna suatu usaha gigih dan bersungguhsungguh untuk membersih dan menyucikan diri seseorang manusia dari sifat-sifat buruk dan keji (mazmumah) yang menjadi penghalang kepada penyuburan akhlak mulia (mahmudah) seseorang insan ${ }^{49}$. Seterusnya penyucian diri

\footnotetext{
${ }^{42}$ Surah al-Shams 91: 9-10.

${ }^{43}$ Sila rujuk surah al-Nisa' 4:49.

${ }^{44}$ Sila rujuk surah al-Baqarah 2:151 dan Ali Imran 3:164.

${ }^{45}$ Sila rujuk surah al-Shams 91:9.

${ }^{46}$ Sila rujuk surah al-Kahfi 18:19

${ }^{47}$ Sila rujuk surah al-Nisa' 4: 49 dan al-Najm 53:32.

48 Lihat Che Zarrina Sa'ari, "Peranan Penyucian Jiwa (Tazkiyah alAnfus) terhadap Pembangunan Insan dalam Masyarakat Bertamadun," (makalah, Seminar Tasawuf Negeri Sembilan 2007, Jabatan Mufti Kerajaan Negeri Sembilan Darul Khusus, 2007), 70.

${ }^{49}$ Ibid.
} 
itu diikuti dengan usaha pengisian dan perhiasan diri supaya proses tersebut menjadi lebih sempurna ${ }^{50}$.

Justeru, dapat difahami bahawa tazkiyah melibatkan proses usaha dan kesungguhan seseorang insan dalam menyelesaikan konflik antara baik dan buruk yang wujud dalam jiwanya ${ }^{51}$. Al-tazkiyah juga dapat dijelaskan sebagai menyucikan jiwa daripada pelbagai kecenderungan buruk dan dosa, dan mengembangkan fitrah yang baik di dalamnya, yang dapat menegakkan prinsip ketekalan dan konsistensi untuk mencapai darjat ihsan ${ }^{52}$.

\section{Pengertian al-Nafs dari Sudut Bahasa dan Istilah}

Al-nafs dapat dikembangkan kepada variasi pengertian yang sangat luas. Dalam ruang lingkup perbincangan yang terhad ini, al-nafs dapat ditonjolkan dengan dua makna utama $^{53}$ iaitu jiwa bermakna roh dan keduanya ialah jiwa bermaksud sesuatu dan hakikatnya. Dalam mendefinisikan maksud al-nafs, Anas Ahmad Karzon mengumpulkan makna al-nafs kepada lima kelompok utama berdasarkan maksud daripada ayat al-Qur'an ${ }^{54}$ iaitu pertamanya roh $^{55}$, kedua diri manusia yang terdiri daripada roh dan jasad ${ }^{56}$, ketiga ialah jiwa yang membawa maksud potensi pemikiran manusia ${ }^{57}$, keempatnya ialah jiwa yang

50 Ibid., 11; Mohd Sulaiman Yasin, Akhlak dan Tasawuf (Bangi: Yayasan Salman, 1992), 220.

${ }^{51}$ Che Zarrina, Peranan Penyucian Jiwa, 70.

52 Anas Ahmad Karzon, Tazkiyatun Nafs: Gelombang Energi Penyucian Jiwa Menurut al-Qur'an dan as-Sunnah di atas Manhaj Salafus Shaalih, terj. H.Emiel Threeska (Jakarta : Penerbit Akbar Media Eka Sarana, 2010), xviii.

${ }^{53}$ Ibn. Manẓūr, Lisān al-'Arab, jilid VI, 233.

${ }^{54}$ Anas Ahmad Karzon, Tazkiyatun Nafs, xix- xx.

${ }^{55}$ Sila rujuk ayat al-Qur'an surah al-An`am 6: 93.

${ }^{56}$ Sila rujuk ayat al-Qur'an surah Luqman $31: 28$.

${ }^{57}$ Sila rujuk ayat al-Qur'an surah al-Naml 27: 14. 
membawa maksud hati (al-qalb) ${ }^{58}$ dan terakhir jiwa yang membawa maksud potensi kebaikan dan keburukan ${ }^{59}$.

Al-nafs sebagaimana yang ditafsirkan oleh Imam alGhazāli pula merumuskan dua pengertian iaitu pertamanya pengertian yang meliputi sifat marah dan hawa nafsu yang ada dalam diri manusia, menjadi punca timbulnya segala sifat kecelaan dalam diri manusia dan makna kedua membawa maksud hakikat diri serta zat sebenar diri manusia itu sendiri ${ }^{60}$. Secara umumnya, jiwa (nafs) boleh difahami sebagai jirim halus (jawhar al-fird) yang bergerak memberi kekuatan kepada kehidupan, perasaan dan kehendak pada diri manusia ${ }^{61}$. Ia merupakan suatu hasrat yang mencetuskan nilai-nilai kekuatan pada diri seseorang insan bagi mencapai naluri kemahuannya ${ }^{62}$.

Justeru, dapat difahami makna al-nafs secara istilahnya ialah sesuatu yang terdapat di dalam diri manusia, yang tidak dapat diketahui wujudnya, yang dapat menerima arahan kebaikan atau keburukan, memiliki pelbagai sifat dan karakter kemanusiaan, juga memiliki pengaruh yang nyata kepada perilaku manusia ${ }^{63}$. Jiwa dengan makna ini mencakupi roh dan hati, dan segala yang ada pada manusia, terdiri daripada potensi pengetahuan yang mampu memisahkan perkara baik dan buruk $^{64}$.

${ }_{59}^{58}$ Sila rujuk ayat al-Qur'an surah al-A`raf 7:205.

59 Lihat surah Qaf 50:16, surah al-Nazi at 79:40-41 dan surah alQiyamah 75:2.

${ }^{60}$ Al-Ghazālì, Ihyā' 'Ulūm al-Dīn, jil. 3 (Beirut: Dār al-Mișriyyah alLubnāniyyah, t.t.), 5. Lihat juga Zakaria Stapa, "Tazkiyat al-Nafs: Kepentingan dan Mekanisme Pelaksanaan," dalam Akidah dan Tasawuf (Kuala Lumpur: Bahagian Hal Ehwal Islam Jabatan Perdana Menteri, 1997), 87.

61 Lihat al-Jurjāni, al-Ta 'rífāt (Beirut: Dār al-Kutub al-'Ilmiyyah, 2000), 239. Lihat juga Che Zarrina, Peranan Penyucian Jiwa, 71.

${ }^{62}$ Che Zarrina, Peranan Penyucian Jiwa, 71.

${ }^{63}$ Anas Ahmad Karzon, Tazkiyatun Nafs, xxi.

64 Ibid. 


\section{Pengertian Tazkiyah al-Nafs}

Setelah memahami makna ungkapan tazkiyah dan al-nafs dalam pengertian bahasa dan istilah, pengkaji mengemukakan makna gabungan kedua-duanya secara epistimologi. Para penyelidik daripada kalangan cendiakawan dan ulama-ulama sufi saling melengkapi makna tazkiyah al-nafs tanpa sebarang percanggahan. Tazkiyah al-nafs bermaksud satu usaha dan proses yang gigih dan bersungguh-sungguh untuk membersih dan menyucikan jiwa dari sifat-sifat yang tercela.

Ianya melibatkan satu proses peralihan daripada jiwa yang kotor, ternoda dan tercemar dengan dosa-dosa menjadi jiwa yang suci bersih ${ }^{65}$. Seperti hati yang tidak mengikut peraturan syariat kepada hati yang mengikut kepada tuntutan syariat, daripada hati yang kafir kepada hati yang mukmin, daripada munafik kepada bersikap jujur, amanah dan berintegriti, sifat dendam digantikan dengan pemaaf, tawaddu', tawakkal dan terkawal dan sebagainya.

Oleh yang demikian, pendekatan tazkiyah al-nafs perlu disimbolisasikan sebagai suatu usaha serius dalam merawat hati secara bersepadu dengan disusuli beberapa pendekatan praktikal dan amalan kerohanian. Dengan adanya usaha mengintegrasikan konsep tazkiyah al-nafs ini dengan teori dan teknik psikospiritual dan psikoterapi masa kini, ianya dapat menghasilkan satu kemahiran

${ }^{65}$ Lihat Sa'ì Hawwā, al-Mustakhlas fī Tazkiyah al-Anfus (Beirut: Dār Ammar, t.t), 10. Mohd Sulaiman, Akhlak dan Tasawuf, 219-220; Sa`id Hawwa, Tarbiyyah al-Ruhaniyyah, terj. Khairul Rafie (Bandung: Pustaka Mizan,1988) 79. Untuk keterangan lanjut mengenai tazkiyah al-nafs ini, sila rujuk Che Zarrina Sa'ari, "Purification of Soul According to Sufis: A Study of al-Ghazali's Theory", Jurnal Akidah dan Pemikiran Islam AFKAR, Bil. 3, (MeiJun 2002), 95-112; Sharifah Basirah Syed Muhsin, "Kaedah Psikoterapi Berasaskan Konsep Maqamat: Kajian Terhadap Kitab Qut Al-Qulub Abu Talib Al-Makki”, (Disertasi Sarjana Usuluddin, Universiti Malaya, 2012), 83. 
dalam menyelesaikan masalah secara komprehensif dari pelbagai aspek tingkah laku, emosi, dan spiritual.

\section{Kaedah Tazkiyah Al-Nafs oleh Syeikh Abdul Qadir Al- Mandili}

Berdasarkan perbincangan dalam Kitab Penawar Bagi Hati, al-Mandili telah membina satu sudut pandang yang jelas tentang konsep penyucian jiwa sebagai suatu penawar atau terapi bagi membina satu struktur komponen jasad manusia yang dilengkapi keperibadian lahir dan batin berlandaskan acuan syarak. Jasad ini akan menzahirkan keelokan tingkah laku dan ketulusan jiwa yang murni bagi mencapai semata-mata keredaan Allah SWT di dunia dan akhirat. Inilah yang dikehendaki oleh Islam dalam melahirkan susuk tubuh yang murni dilengkapi jiwa yang suci iaitu melalui proses tazkiyah alnafs.

Proses untuk mencapai kesempurnaan tazkiyah alnafs menurut al-Mandili dapat diformulasikan kepada suatu bentuk kaedah tazkiyah al-nafs dengan membahagikannya kepada empat peringkat. Peringkatperingkat tazkiyah al-nafs menurut al-Mandili dapat dijelaskan seperti berikut:

Peringkat Pertama: $\begin{aligned} & \text { Kawalan Anatomi Jasmani } \\ & \text { Manusia }\end{aligned}$

Peringkat Kedua: Penyingkiran Elemen Negatif

Peringkat Ketiga: Penerapan dan Pemantapan Sifat

Positif

Peringkat Keempat: Penstabilan dan Penyerahan Diri

\section{Peringkat Pertama: Kawalan Anatomi Jasmani Manusia}

Peringkat pertama untuk membentuk kaedah tazkiyah alnafs menurut pemikiran tasawuf Syeikh Abdul Qadir alMandili ialah dengan kaedah kawalan anatomi jasmani manusia. Al-Mandili mempunyai asas yang kukuh apabila meletakkan anggota zahir manusia sebagai satu elemen penting dalam pendidikan kejiwaan. Anatomi 
dimaksudkan sebagai kajian atau pengetahuan mengenai binaan tubuh dan hidupan seperti manusia ${ }^{66}$. Insan yang hendak mencapai jiwa yang diredai dan suci perlu mengenal struktur tubuh badannya dan melihat kebesaran Allah SWT melalui kejadiannya sebagai manusia yang sempurna dan berakal.

Al-Mandili percaya bahawa tubuh badan jasmani manusia memberi impak penting mengukuhkan kedudukan sifat terpuji dalam konstruk ilmu tasawuf. Beliau di awal kitab telah menjelaskan ${ }^{67}$ :

"..dan ketahuilah bahawasanya maksud daripada ilmu tasawuf itu membersihkan segala anggota yang zahir daripada segala perbuatan yang keji, supaya ada ia menyampaikan kepada membersihkan hati daripada segala sifat kecelaan..”.

Al-Mandili telah memilih tujuh anggota jasmani manusia sebagai elemen pertama yang perlu dikawal dan dijaga. Tujuh anggota tersebut adalah mata, telinga, lidah, perut, faraj serta sepasang kaki dan tangan ${ }^{68}$. Dalam fasa ini, al-Mandili telah menjalankan teknik patologi, iaitu suatu kaedah cabang perubatan dan rawatan yang mengkaji sebab, punca, proses perkembangan dan akibat penyakit ${ }^{69}$. Al-Mandili telah mengambil pendekatan menerangkan faedah dan manfaat dunia dan akhirat, terhasil daripada anggota jasad terpilih. Ini adalah suatu momentum penting bagi menyampaikan kesedaran dan penghayatan kepada manusia tentang kesempurnaan penciptaan Allah SWT yang dikurniakan kepada hambahamba-Nya dan wajib disyukuri.

Kepentingan kaedah ini dijadikan asas awal menyampaikan manusia kepada pengajian tasawuf dan

\footnotetext{
${ }^{66}$ Kamus Dewan ed. ke-4, 52, entri “anatomi”.

${ }^{67}$ Al-Mandili, Penawar Bagi Hati, 4.

${ }^{68}$ Ibid.

${ }^{69}$ Kamus Dewan ed. ke-4,1149, entri “patologi”.
} 
akhlak tidak dapat disangkal lagi kerana anggota tubuh badan manusia merupakan satu talian yang sangat hampir dan terpamer untuk memusatkan tumpuan hati kepada konsep tazkiyah al-nafs. Pada peringkat ini, al-Mandili telah menekan konsep penghayatan dalam hati terhadap nikmat segala anggota tubuh badan yang dikurniakan oleh Allah SWT kepada hamba-hambaNya. Pengkaji menafsirkan penghayatan yang dimaksudkan ialah kefahaman kepada dua isu utama iaitu memelihara anggota tubuh dengan mengelak keburukan dan keduanya memelihara anggota tubuh dengan menjadikannya dalam lingkungan kebaikan.

Secara terperinci dapat diterangkan ialah kewajiban manusia memelihara segala anggota daripada bahaya dan kerosakan yang dilihat dari sudut kerosakan yang boleh terjadi akibat perbuatan diri sendiri, juga kerosakan pahala dan ibadah akibat perlakuannya di dunia. Turut juga difahami kewajiban memelihara anggota itu ialah dengan mengarahkan segala anggota tubuh badan manusia kepada kebaikan dan kebajikan agar ianya menjadi wasilah mendapatkan pahala yang akan dinilai di akhirat.

Kemuncak pembentukan kaedah peringkat pertama ini adalah manifestasi kesyukuran hamba kepada Allah SWT dengan melalui jalan-jalan yang membawa fungsi anggota tubuh badan tersebut kepada ibadah dan pahala di sisi Allah SWT Ini dijelaskan oleh al-Mandili dalam frasa ungkapan beliau ${ }^{70}$ :

“...dan iaitu segala anggota engkau, yang wajib atas engkau memeliharanya dan mensyukurkannya. Maka jika tiada memelihara engkau akan dia nescaya selagi jadi saksi semuanya atas engkau pada hari kiamat..."

${ }^{70}$ Ibid., 4. 
Ahli pemikir Barat tidak pernah ketinggalan dalam melihat perkembangan tubuh jasmani manusia sebagai elemen penting yang mempengaruhi sikap dan tingkah laku manusia. Sebagai contoh, Sigmund Freud (18561939M) seorang doktor neurologi yang memperkenalkan kaedah terapi psikoanalitik ${ }^{71}$ turut memberi tumpuan kepada pendekatan ketingkahlakuan (behaviorism) dan pendekatan kewujudan kemanusiaan (humanistic existential). Freud telah membahagikan peringkat perkembangan personaliti manusia kepada lima peringkat yang memperlihatkan penekanan dan ciri-ciri tertentu. Antaranya ialah peringkat mulut atau oral stage (0-1 tahun), peringkat dubur atau anal stage (2-3 tahun), peringkat zakar dan faraj (4-5 tahun), peringkat latensi atau latency period (6-12 tahun) dan terakhir peringkat syahwat atau genital stage (12 tahun ke atas).

Biarpun pengkaji mendapati Freud sering mengaitkan perkembangan personaliti setiap individu lebih menjurus kepada pengalaman seksualiti, namun beliau tidak menolak pengaruh perkembangan jasmani manusia mempengaruhi tabiat dan tingkah laku negatif dalam diri manusia itu sendiri. Contohnya seperti menurut Freud, orang dewasa yang makan banyak, suka mengunyah, suka bercakap banyak, suka menghisap rokok banyak dan ketagihan arak adalah orang-orang dewasa yang

71 Othman Mohamed menjelaskan teori psikoanalitik berasaskan andaian bahawa manusia itu melalui pemeringkatan evolusi. Desakan yang lahir secara semulajadi amat penting dalam mempengaruhi apa sahaja kehendak tingkah laku yang bersemadi dalam desakan naluri manusia. Terapi ini juga melihat hipotesis topografi yang bermaksud terdapat hubungan antara minda sedar dengan tidak sedar. Hipotesis dinamik melihat minda sebagai satu bentuk tenaga sistem yang tertutup dimana setiap kesan adalah penyebab. Lihat Othman Mohamed, Prinsip Psikoterapi dan Pengurusan Dalam Kaunseling (Serdang: UPM Press, 2005). Lihat juga Sapora Sipon dan Ruhaya Hussin, Teori Kaunseling dan Psikoterapi, ed. ke-3 (Nilai : Penerbit Universiti Sains Islam Malaysia, 2012), 24. 
perkembangan personalitinya terlekat pada peringkat oral incorporative. Manakala orang dewasa yang memperlihatkan tindakan-tindakan sindiran, agresif, suka mengumpat atau membuat komen-komen yang menyakitkan adalah terlekat pada peringkat oral agggresive $^{72}$.

Contoh nilai dan perbuatan negatif yang diumpamakan oleh Freud sangat sinonim dengan sifat mazmumah yang perlu disingkirkan dalam kaedah tasawuf Islam. Jelas sekali sifat-sifat tersebut tertolak daripada norma dan budaya murni masyarakat yang berbilang di dunia ini. Cetusan tindakan dan respon negatif yang dizahirkan oleh tubuh badan manusia adalah suatu yang ditolak oleh semua ruang pandang merentasi varian budaya, agama dan adat kebiasaan masyarakat.

Namun, dalam pembentukan diri yang mempunyai moraliti yang baik, sarjana Barat memilih pelbagai agen dan pendekatan untuk menghasilkan sikap-sikap yang baik seperti yang diistilahkan sebagai gerakan minda, dorongan naluri dalaman, kesedaran tanggungjawab individu dan pelbagai istilah lain yang merujuk kepada mendidik tingkah laku kepada perkara kebaikan.

Al-Mandili mempunyai satu frasa yang berbeza dalam membentuk anggota zahir manusia yang dipandu dengan akhlak yang baik. Beliau menggunakan pendekatan kesedaran dalam diri manusia untuk menzahirkan kesyukuran kepada Allah SWT sebagai Tuhan yang menciptakan segala nikmat anggota tubuh badan manusia. Kaedah al-Mandili dalam mengawal anggota tubuh badan manusia ialah dengan menzahirkan kesyukuran kepada Allah SWT melalui kaedah-kaedah berikut:

1. Mata: Memelihara daripada perkara-perkara yang diharamkan oleh syarak seperti melihat wanita yang

${ }^{72}$ Sapora Sipon dan Ruhaya Hussin, Teori Kaunseling dan Psikoterapi, 32-34. 
bukan isterinya, atau sahayanya atau mahramnya. Juga haram melihat pemuda yang belia dan melihat aurat lelaki.

2. Telinga: Memelihara daripada mendengar yang dilarang oleh syarak seperti mengumpat, mengadu domba, perkataan bid'ah, mendengar suara perempuan jika mengundang fitnah.

3. Lidah: Memelihara daripada berkata dan menggunakannya dalam perkara yang dilarang oleh syara', seperti berdusta, mengumpat dan menyakiti orang lain.

4. Perut: Memelihara perut daripada memakan dan meminum apa jua yang haram. Begitu juga perkaraperkara syubhat (tiada yakin halalnya) dan tidak makan sehingga terlalu kenyang.

5. Faraj: memelihara daripada yang diharamkan seperti zina dan liwat dan memelihara juga daripada nikah yang batil (tidak sah).

6. Kaki dan tangan: Menggunakan kedua pasang anggota ini untuk melakukan ketaatan dan menghindari maksiat.

Dalam merawat patologi manusia, kefahaman dan keupayaan mentafsir tahap dan kedudukan nafs individu adalah penting supaya dapat menjalankan intervensi penerokaan ke tahap selanjutnya. Nafs menurut Othman Hj. Mohamed mengandungi pelbagai bentuk, pola, kederiaan, idea, ingatan dan perasaan bagi membolehkan pengasingan antara dimensi ikatan hubungan dengan ruh di peringkat atas, di samping mewujudkan juga ikatan hubungan dengan jasad manusia pada peringkat bawah ${ }^{73}$.

73 Sila rujuk Othman Mohamed, Prinsip Psikoterapi dan Pengurusan, 33. Penulis telah memperkenalkan pendekatan Psikologi Kognitif Ad-Din (Terapi Kognitif Ad-Din) dalam bidang psikoterapi. Lihat Sapora Sipon dan Ruhaya Hussin, Teori Kaunseling dan Psikoterapi, 255. 
Malik Bennabi (1905-1973M) seorang sarjana Muslim dalam bidang falsafah sosial menyifatkan pertumbuhan seorang insan terdiri daripada dua unsur penting iaitu pertama pertumbuhan secara fizikal dan biologi (biosphere) dan unsur kedua adalah pertumbuhan bukan fizikal iaitu aspek psikologi. Manakala kebudayaan adalah manifestasi fizikal daripada hubungan individu dengan alam tersebut, iaitu alam rohani (noosphere) ${ }^{74}$. Kebudayaan diistilahkan oleh Bennabi sebagai "suatu kumpulan sifat-sifat akhlak dan nilai-nilai masyarakat, yang boleh memberikan pengaruh terhadap individu sejak kelahirannya, dan dengan tanpa disedari ia menjadi suatu perhubungan yang mengikat tingkah lakunya dengan cara kehidupan $^{75}$. Ianya adalah suatu fenomena sosial yang hidup dan tidak hanya sebagai warisan yang mati ${ }^{76}$."

Pernyataan tersebut membenarkan penilaian alMandili bahawa jasad fizikal manusia memainkan peranan yang sangat penting bagi pembentukan nilai kerohanian dan kejiwaan seseorang individu. Setelah menilai anggota zahir sebagai elemen yang perlu diberi perhatian dan dirawat, al-Mandili melanjutkan fasa seterusnya kepada pemurnian hati dengan mengembalikan fitrah kejernihan hati manusia. Jiwa dan hati manusia perlu disediakan dengan ruang untuk berubah kepada kebaikan. Tindakan penting yang perlu dilaksanakan adalah dengan menyingkirkan elemen-elemen negatif dalam hati sanubari manusia.

${ }^{74}$ Mālik Bennabī, Mushkilāt al-Thaqāfah, terj. 'Abd al-Sabūr Shāhin (Damsyik: Dar al-Fikr, 1989), 76-77. Lihat juga Usman Shihab, "Agama dan Perubahan Masyarakat menurut Malik Bennabi", Jurnal Akidah dan Pemikiran Islam (Afkar), Bil. 10 (Mac 2009), 137-138.

75 Mālik Bennabì, Milād Mujtama', terj. 'Abd al-Sabur Shahin (Damsyik: Dār al-Fikr, 1987), 74. Rujuk Usman Shihab, Agama dan Perubahan Masyarakat, 137-138.

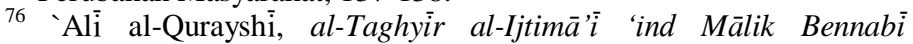
(Kaherah: al-Zahrā li al-I'laām, 1989), 169. 


\section{Peringkat Kedua: Penyingkiran Elemen Negatif}

Manusia tidak boleh mengelak daripada menjalani proses kembali kepada fitrah manusia bagi menyempurnakan hasrat mencapai tahap pemurnian jiwa. Al-Qur'an banyak menyebutkan bahawa asal fitrah manusia itu suci dan berada di landasan syariat, namun fitrah manusia mudah melentur mengikut pengaruh positif dan negatif daripada persekitaran, acuan nafsu dan keinginan diri. Al-Qur'an memandu fitrah manusia untuk kembali kepada kebenaran dan kejadian fitrah yang sebenar seperti firman Allah SWT:

Terjemahan : (setelah jelas kesesatan syirik itu) maka hadapkanlah dirimu (engkau dan pengikut-pengikutmu, wahai Muhammad) ke arah agama yang jauh dari kesesatan; (turutlah terus) agama Allah, iaitu agama yang Allah menciptakan manusia (dengan keadaan bersedia dari semulajadinya) untuk menerimanya; tidaklah patut ada sebarang perubahan pada ciptaan Allah itu; itulah agama yang betul lurus, tetapi kebanyakan manusia tidak mengetahui. ${ }^{77}$

Al-Ghazāli melihat secara fitrahnya, jiwa manusia mempunyai kemampuan untuk responsif dan memahami pengetahuan yang tidak dapat dilihat oleh mata ${ }^{78}$. Jiwa memiliki dua kekuatan iaitu kekuatan bersifat praktikal (quwwah al-'amaliyyah) dan kekuatan bersifat teoritikal (quwwah al-'älimah). Kedua-duanya saling melengkapi dan berfungsi seperti penggerak (motor) dan perangsang (stimulator). Kekuatan teoritikal menerima segala ilmu

\footnotetext{
${ }^{77}$ Surah al-Rum 30:30.

78 Al-Ghazālī, Mi'rāj al-Sālikīn (Kaherah: Silsilaṭ al-Thaqāfah alIslāmiyyah, 1964), 70-71. Sila rujuk juga M. Solihin, Penyucian Jiwa dalam Perspektif Tasawuf al-Ghazali (Bandung: CV Pustaka Setia, 2000), 79-80.
} 
yang tidak terbatas, dan keupayaan fizikal merupakan refleksi kepada pengetahuan yang ada padanya ${ }^{79}$.

Namun, apa yang kerap berlaku ialah penyelewengan fitrah berpunca daripada agen-agen pengaruh negatif dan godaan yang hebat memesongkan manusia daripada jalan kebenaran. Tetapi, dengan rahmat, keampunan dan pertolongan daripada Allah SWT, disertai dengan jasad dan hati yang mempunyai prakarsa untuk membaiki diri menurut lunas syarak, maka manusia akan dapat mengembalikan potensi diri kepada asal tujuan penciptaannya $^{80}$.

Terapi penyingkiran elemen negatif ini selari dengan penilaian deskriptif iaitu input kerosakan perlu melalui proses pemurnian untuk menghasilkan output kebaikan. Teknik ini boleh difahami dan diperjelaskan dengan pengajaran yang diambil daripada ayat al-Qur'an daripada sepotong ungkapan Allah SWT:

Terjemahan: Dan janganlah kamu berbuat kerosakan di bumi sesudah Allah menyediakan segala yang membawa kebaikan padanya, dan berdoalah kepadanya dengan perasaan bimbang (kalau-kalau tidak diterima) dan juga dengan perasaan terlalu mengharapkan (supaya makbul). Sesungguhnya rahmat Allah itu dekat kepada orang-orang yang memperbaiki amalannya. ${ }^{81}$

Al-Mandili telah memilih sepuluh sifat tercela yang paling utama daripada begitu banyak sifat mazmumah yang perlu disingkirkan daripada diri dan hati manusia. Sifat-sifat kecelaan itu ialah kerakusan terhadap makanan, loba bercakap dan berkembur ${ }^{82}$, marah, dengki, kedekut

${ }^{79}$ Ibid.

${ }^{80}$ Che Zarrina, Peranan Penyucian, 77.

${ }^{81}$ Surah sl-A'raf 7:56.

82 Berkembur dimaksudkan sebagai perbualan kosong; berkemburkembur bercakap-cakap untuk menghabiskan waktu (sambil 
dan kasih akan harta, kasih kepada kemegahan, kasih kepada dunia, suka membesarkan diri, 'ujub dan riya'.

Pada fasa kedua ini, seseorang perlu mendiagnosis dan bermuhasabah dengan segala sifat tercela yang ada dalam dirinya. Sifat-sifat ini perlu diteroka, difahami dan dikenalpasti punca dan penyebab timbulnya dalam diri dan hati manusia. Dengan kefahaman yang jelas tentang sesuatu masalah, seseorang akan mudah mengintervensi dan memandu sifat dan sikapnya untuk merawat kerosakan dan keburukan yang ada.

Naumana Amjad berpendapat bahawa hati manusia (al-qalb) mengandungi konstruk pengenalpastian (alwajd) yang boleh difahami dengan penyatuan diri manusia dengan rahmat roh ${ }^{83}$. Sebagai satu konstruk, pengenalpastian membantu dan memudahkan qalb dan roh menuju ke mercu transendental spiritual ${ }^{84}$. Perhubungan ini dimudahkan dengan segala percontohan watak yang kamil sebagai ciri yang diidamkan oleh insan untuk mencapai mercu transendental spiritual tersebut ${ }^{85}$.

Pada fasa seterusnya dalam usaha peringkat penyingkiran elemen negatif, al-Mandili dilihat telah memfokuskan proses rehabilitasi iaitu satu usaha dan kaedah pemulihan kepada kerosakan jiwa yang timbul agar kembali kepada asal fitrah manusia yang suci dan murni. Justeru, al-Mandili telah memberi penekanan

bergurau senda dan sebagainya), berbual-bual kosong, berborakborak. Lihat Kamus Dewan ed. ke-4, 732, entri "kembur".

${ }^{83}$ Amjad N. seorang pakar Psyche di Islamic Gnostic and Philosophical Tradition, menulis dalam Quranic Concepts of Human Psyche, sunt. Zafar Afaq Ansari (Islamabad: International Institute of Islamic Thought, 1992), 39-56. Lihat Sapora Sipon dan Ruhaya Hussin, Teori Kaunseling dan Psikoterapi, 257.

84 Transendental diertikan sebagai idea, fahaman, pengalaman yang sukar difahami dengan menggunakan pemikiran logik biasa, ghaib, abstrak. Sila lihat Kamus Dewan ed. ke-4, 1712, entri "transendental".

${ }^{85}$ Amjad, Quranic Concepts, 39-56. 
penting dalam mengembalikan fitrah asal murni manusia yang telah dicemari gejala sifat yang tercela.

Oleh kerana itu, setelah menjalani proses mengenalpasti sifat-sifat cela yang wujud dalam diri, seseorang perlu berusaha menangani dan mengawal kemudaratan yang timbul daripada sifat-sifat ini melalui penawar dan rawatan yang berlandaskan bimbingan syarak. Al-Mandili secara jelas telah menerangkan kesemua ini dalam huraian dan analogi yang mudah difahami. Melalui kaedah ini, setiap individu dipercayai mempunyai daya dan kebolehan yang tersendiri dalam menilai perwatakan dan potensi naluri yang ada dalam dirinya. Dengan keupayaan tersebut, manusia mampu meleraikan dan meluhurkan sifat kecelaan dirinya bagi mengawal diri dan persekitarannya untuk melahirkan respon dan tindak balas yang baik dan positif.

\section{Peringkat Ketiga : Pemantapan Sifat Positif}

Jiwa manusia perlu diadun untuk menjana sahsiah yang sempurna dan membina prosedur ketulenan, iaitu istilah yang digunakan dalam psikoterapi sebagai kebolehan untuk menjadi sejati dan benar dengan orang lain ${ }^{86}$. Enam sifat yang dipuji seperti yang telah disenaraikan oleh alMandili iaitu sifat taubat, khawf, zuhud, sabar, ikhlas dan tawakkal memerlukan usaha dan ikhtiar daripada tenaga yang dihasilkan melalui kekuatan jiwa dan kerjasama daripada perlakuan zahir manusia bagi mencapai maksud tersebut.

Peringkat ini memerlukan usaha peneguhan, pemantapan dan melazimkan kelakuan-kelakuan yang terpuji menurut syarak agar kehidupan manusia terpandu dan berada di dalam ruang lingkup agama. Penerapan nilai positif (positive value) dalam jiwa dapat dilaksanakan apabila manusia telah berjaya meleraikan dirinya daripada

${ }^{86}$ Sapora Sipon dan Ruhaya Hussin, Teori Kaunseling dan Psikoterapi, 321. 
belenggu sifat mazmumah. Hati dan jiwa yang mencari kebenaran akan mula memenuhkan ruang hatinya dengan sifat-sifat kepujian iaitu sifat mahmudah. Kaedah ini sangat menepati perintah Allah SWT yang disebutkan dalam firman-Nya:

Terjemahan: Sesungguhnya amal-amal

kebajikan itu menghapuskan kejahatan. ${ }^{87}$

Mengendali dan mengawal nafsu serta keinginan kepada akhlak-akhlak terpuji merupakan suatu prakarsa, iaitu inisiatif, daya usaha dan ikhtiar yang perlu dilakukan oleh diri sendiri, berpandukan iman dan ilmu pengetahuan, bersendikan panduan hukum syarak, serta yang paling utama perubahan kepada nilai positif ini perlu dipayungi oleh rahmat dan keredaan daripada Allah SWT Dalam menjelaskan hal ini, al-Mandili telah menerangkan tentang ciri-ciri ideal untuk mencapai setiap sifat yang mulia iaitu sifat taubat, khawf, zuhud, sabar, ikhlas dan tawakkal dengan gayanya yang tersendiri.

Konsep ketekalan dan konsistensi pula merupakan suatu tipologi penting dalam usaha mencapai tazkiyah alnafs. Allah SWT telah mengajar manusia teknik mengekalkan konsistensi sebagai benteng membentuk jati diri yang sejati. Di dalam al-Qur'an terdapat beberapa ayat yang mengingatkan manusia agar selalu istiqamah dalam segala urusan agama. Firman Allah SWT:

Terjemahan: Oleh itu, hendaklah engkau (wahai Muhammad) sentiasa tetap teguh di atas jalan yang betul sebagaimana yang diperintahkan kepadaMu. ${ }^{88}$

Al-Mandili sering mengingatkan bahawa sifat-sifat ini perlu dihadam dan dilazimkan dalam perlakuan manusia agar ianya menjadi resam yang tidak memerlukan paksaan dan kepura-puraan. Akhlak yang terpuji dan sosialisasi yang berlandaskan nilai murni adalah elemen

\footnotetext{
${ }^{87}$ Surah Hud 11:114.

${ }^{88}$ Surah Hud 11:112.
} 
yang sangat penting dalam membina jaringan sosial dalam masyarakat, apatah lagi membina sebuah negara yang maju dan kompeten. Sesuatu bangsa yang berharap untuk membina fenomena ketamadunan yang bernilai tidak boleh mengesampingkan akhlak dan budi pekerti yang baik untuk membina peradabannya yang unggul ${ }^{89}$.

Justeru, nilai akhlak yang murni dan sebati dalam diri individu perlu menjadi unsur dominan dan mutasi untuk menghasilkan masyarakat yang berakhlak dan bermoral tinggi. Ini kerana membentuk insan-insan berakhlak adalah suatu nilai penting dalam membina bangsa, manakala keutuhan jati diri yang terlazim dan tekal dengan akhlak dan nilai yang dipuji oleh syarak menjadi elemen penting kepada dasar membina insan kamil, jaringan sosial yang mantap dan tamadun bangsa yang terbilang. Setelah menjalani proses konsistensi, jiwa manusia telah berada di peringkat akhir iaitu peringkat penstabilan dan penyerahan diri kepada Allah SWT semata-mata.

\section{Peringkat Keempat: Proses Penstabilan dan Penyerahan Diri}

Peringkat terakhir yang perlu dilalui oleh seorang insan bagi mencapai kemuncak pencapaian spiritual insan iaitu tazkiyah al-nafs disebut oleh al-Mandili disempurnakan melalui empat sifat mahmudah iaitu kasih akan Allah SWT, reda dengan qada' Allah SWT, ingat kepada kematian dan landasan utama pada peringkat ini menurut al-Mandili adalah sifat syukur. Fasa akhir penentuan sifat mahmudah yang dipilih oleh al-Mandili telah menjelaskan unsur penting yang ingin dicapai oleh jiwa manusia. Setelah melalui proses mengosongkan hati daripada sifat mazmumah, disusuli proses pemurnian, rehabilitasi dan pelaziman sifat-sifat mahmudah dalam diri, akhirnya

${ }^{89}$ Hashim Musa, Merekonstruksi Tamadun Melayu Islam: Ke Arah Pembinaan Tamadun Dunia Alaf Ketiga (Kuala Lumpur: Akademi Pengajian Melayu, Universiti Malaya, 2001), 24. 
manusia akan mula mencapai ketenangan dan penyerahan diri kepada semata-mata hanya untuk Allah SWT.

Perbicaraan disiplin ilmu tasawuf memberi penekanan penting kepada tahap nafs atau jiwa manusia. Al-Qur'an secara jelas memperincikan tiga kelompok jiwa manusia yang digelar sebagai al-nafs al-muța'innah, alnafs al-lawwāmah dan terakhir al-nafs al-ammārah. Jelasnya, al-nafs al-muța'innah menduduki mercu teratas dipenuhi dengan ketenangan dan kedamaian yang Allah SWT anugerahkan kepada para Nabi dan para wali Allah. Ianya sejenis jiwa yang paling mulia kerana telah dipenuhi sinaran cahaya sehingga menghakis kesemua sifat buruk dan dihiasi pula dengan sifat mulia ${ }^{90}$.

Al-Mandili secara tidak langsung meletakkan empat sifat terakhir yang dipuji syarak di dalam susunan kitabnya yang dapat difahami oleh pengkaji sebagai hierarki kemuncak mencapai jiwa yang tenang, jiwa yang suci dan mercu usaha tazkiyah al-nafs. Ketenangan dan kebahagiaan itu boleh dihasilkan melalui jiwa yang telah stabil dan tetap dalam membangunkan jiwa-jiwa murni dan terpuji. Justeru stabiliti adalah suatu perkara yang perlu diusahakan agar jiwa terdidik menempuh kesukaran dan ujian mendatang dengan rasa nikmat dan kesyukuran.

Al-Ghazāli menyifatkan fitrah jiwa manusia memiliki dua kecenderungan yang sama kekuatannya iaitu kecenderungan kepada malaikat dan kecenderungan kepada haiwan ${ }^{91}$. Apabila manusia memanfaatkan jiwanya untuk menyerah diri kepada Allah SWT dan berkelakuan dengan sifat-sifat terpuji, maka dia tergolong dalam kecenderungan malaikat. Sebaliknya, jiwa yang mengikut

90 Che Zarrina, Peranan Penyucian Jiwa, 71. Rujuk al-Jurjānī, alTa'rifät, 239.

91 Che Zarrina Sa'ari, Al-Ghazali and Intuition: An Analysis, Translation and Text of al-Risalah al-Laduniyyah (Kuala Lumpur: University of Malaya, 2007), 39-40. 
hawa nafsu maka dia menghampiri kecenderungan haiwan.

Bagi menyelesaikan masalah pertentangan dua jiwa ini, al-Ghazali mengusulkan konsep keseimbangan (i tidāl). Apabila keseimbangan diaplikasikan dalam jiwa akan melahirkan manusia yang dikawal oleh jiwa yang fitrah dan membebaskan dirinya daripada belenggu hawa nafsu $^{92}$. Ketenangan dan kebahagiaan merupakan ciri umum dalam aliran tasawuf kerana tujuan ilmu tasawuf untuk menyekat dan membataskan tuntutan syahwat fizikal bagi tujuan mendapatkan kestabilan jiwa, yang menjadikan diri seseorang itu bebas daripada kebimbangan dan merasai ketenangan jiwa dan kebahagiaan dalam hidupnya ${ }^{93}$.

Justeru dapat disimpulkan bahawa tahap penstabilan dan ketenangan jiwa yang diperolehi oleh insan yang sentiasa menuntut keredaan Allah SWT, mengawal tindak tanduk perlakuan zahir, sentiasa mengkoreksi kelemahan yang lahir daripada sifat-sifat buruk dan akhirnya kekal di dalam amalan dan sifat yang dipuji oleh syarak telah mencapai terma penyempurnaan tazkiyah al-nafs. Jiwajiwa ini akan sentiasa ingin menambah kebaikan dan Allah SWT turut menambah satu tingkatan kebaikan lagi dalam jiwa tersebut, dan akhirnya Allah SWT pancarkan kebaikan yang terbit daripada air muka dan jiwa mereka.

Mereka adalah orang-orang yang menunjukkan potensi dan prestasi yang baik daripada sudut akidah yang benar dan amalan yang baik, mengikuti jalan yang lurus dengan sebenar dan memahami undang-undang alam yang

${ }^{92}$ M. Solihin, Penyucian Jiwa, 80-81.

93 Abu al-Wafa' al-Ghanimi al-Taftazani, Perkembangan Tasawuf Islam, terj. Abdul Shukor Husin dan Mudasir Rosder (Kuala Lumpur: Bahagian Hal Ehwal Islam, Jabatan Perdana Menteri, 1996), 5. 
membawa mereka dekat dengan syurga Allah $\mathrm{SWT}^{94}$ sebagaimana difirmankan-Nya:

Terjemahan: Untuk orang-orang yang berusaha menjadikan amalnya baik dikurniakan segala kebaikan serta satu tambahan yang mulia, dan air muka mereka pula (berseri-seri) tidak diliputi oleh sebarang kesedihan dan kehinaan. Mereka itulah ahli syurga, mereka kekal di dalamnya selama-lamanya. ${ }^{95}$

Al-Ghazāli berpendapat bahawa kebahagiaan adalah tujuan akhir bagi orang yang melakukan penyucian jiwanya ${ }^{96}$. Kelazatan dan kenikmatan dunia bergantung kepada nafsu dan akan hilang apabila manusia mati. Sedangkan kelazatan dan kenikmatan melihat Tuhan bergantung kepada qalb dan ianya tidak akan mati, malah kenikmatannya akan bertambah kerana dapat keluar daripada kegelapan menuju cahaya terang ${ }^{97}$.

\section{Penutup}

Syeikh Abd al-Qadir al-Mandili merupakan antara teknokrasi yang menggabungkan kepakaran jiwa dengan perubahan teknikal lahiriah dalam membangun jiwa manusia secara kolektif dan bersistem dekad ini. Beliau selari dan jelas mengikuti perjalanan ulama-ulama tasawuf terdahulu seperti Imam al-Qushairi (m.465H/1073M), Imam al-Ghazāli (m.505H/1111M) dan lain-lain lagi yang jelas disebutkan dalam tulisan beliau

94 Sila rujuk Sayyid Qutb, Tafsir Fi Zilalil Qur'an: Di Bawah Bayangan al-Qur'an, jil. 8, terj. Yusoff Zaky Haji Yacob (Kota Bharu, Kelantan: Pustaka Aman Press, 2000), 232. Rujuk juga Jalaluddin Muhamad al-Mahalli al-Suyuti, Tafsir Jalalain, j.2, terj. Najib Junaidi (Surabaya: PT. eLBA Fitrah Mandiri Sejahtera, 2010), 35.

${ }^{95}$ Surah Yunus 10:26.

96 Lihat Al-Ghazālì, Kimiyā' al-Sa ādah (Beirut: al-Maktabah alShi 'biyyah, t.t.), 130-132; Rosihan Anwar dan Mukhtar Solihin, Ilmu Tasawuf (Bandung: Pustaka Setia, 2004), 116-117.

97 Ibid. 
bagi memperjelas nilai-nilai akhlak yang banyak disebutkan di dalam al-Quran. Penulisan beliau dalam kitab Penawar Bagi Hati yang menyediakan sistem dan kaedah tazkiyah al-nafs berpaksikan ketauhidan kepada Allah SWT dan nilai pendidikan rabbani merupakan satu usaha gigih menyampaikan kepada masyarakat hari ini kepada jalan-jalan yang telah dilalui oleh Nabi Muhammad s.a.w, para ahli keluarga Baginda s.a.w dan diteruskan oeh para sahabat dan para tabi'in.

Kaedah penterjemahan konsep dan kaedah tazkiyah al-nafs beliau bersifat dekoratif, praktikal dan mudah difahami bagi mereka yang bercita-cita untuk membantu diri dan jiwa menyingkirkan sifat kecelaan yang sukar dilenyapkan di dalam hati apatah lagi berdepan dengan dunia yang penuh cabaran. Manakala panduan mengekalkan manusia dalam sifat terpuji merupakan resepi dan ramuan istimewa yang memerlukan dedikasi dan kesungguhan diri dan jiwa untuk melaksanakannya.

Kaedah tazkiyah al-nafs berdasarkan pemikiran alMandili disusun dengan metode yang jelas, teliti dan bersepadu. Masyarakat yang mempunyai kepelbagaian latar belakang pendidikan, pemikiran, asuhan keluarga dan kecelaruan budaya akan dapat memahami dan mengadaptasi keluhuran akhlak dan budi pekerti dengan mudah dan jelas. Kaedah ini jika diperhalusi akan menemukan kepada jiwa hamba yang ingin kembali kepada Tuhannya. Justeru, tidak ternafi limpah kurnia rahmat, kasih sayang dan taufiq inayah daripada Allah SWT merupakan satu unsur paling tinggi yang akan merahmati dan membuka ruang terlaksananya kaedah ini selayaknya dalam diri seorang hamba. Manusia perlu menanam azam yang bersungguh-sungguh diiringi prakarsa melaksanakan dan menjayakan kaedah ini sepenuh hatinya. Di penghujung pencarian, jiwa-jiwa ini mengharapkan ketenangan hidup di dunia dan kekal 
kehidupan di syurga yang dijanjikan oleh Allah SWT di akhirat kelak.

\section{Rujukan}

Abdul Razak Mahmud, "Haji Husain Che Dol (19041967)." Dalam Tokoh-tokoh Ulama' Semenanjung Melayu (2), ed. Ismail Che Daud. Kota Bharu: Majlis Agama Islam dan Adat Istiadat Melayu Kelantan, 2007. Ahmad Fathi al-Patani. Ulama' Besar daripada Pattani, Edisi Rumi. Bangi: Penerbit UKM, 2002.

Amjad, N. Quranic Concepts of Human Psyche, sunt. Zafar Afaq Ansari. Islamabad: International Institute of Islamic Thought, 1992.

Bennabī, Mālik. Milād Mujtama', terj. 'Abd al-Ṣabūr Shāhin. Damsyik: Dār al-Fikr, 1987.

Bennabī, Mālik. Mushkilāt al-Thaqāfah, terj. 'Abd alȘabūr Shāhin. Damsyik: Dār al-Fikr, 1989.

Che Zarrina Sa'ari, "Purification of Soul According to Sufis: A Study of al-Ghazali's Theory", AFKAR Bil. 3, (Mei-Jun 2002).

Che Zarrina Sa'ari. "Peranan Penyucian Jiwa (Tazkiyah Al-Anfus) terhadap Pembangunan Insan Dalam Masyarakat Bertamadun." Makalah, Seminar Tasawuf Negeri Sembilan 2007, Jabatan Mufti Kerajaan Negeri Sembilan Darul Khusus, 2007.

Che Zarrina Sa'ari. Al-Ghazali and Intuition: An Analysis, Translation and Text of al-Risalah al-Laduniyyah. Kuala Lumpur: University of Malaya, 2007.

Al-Ghazāli. Ihyā' 'Ulūm al-Dīn, jil. 3. Beirut: Dār alMișriyyah al-Lubnāniyyah, t.t.

Al-Ghazāli. Kimiyā' al-Sa 'ādah. Beirut: al-Maktabah alShi`biyyah, t.t.

Al-Ghazālí. Mi'rāj al-Sālikīn. Kaherah: Silsilat alThaqāfah al-Islāmiyyah, 1964.

Hashim Musa. Merekonstruksi Tamadun Melayu Islam: Ke Arah Pembinaan Tamadun Dunia Alaf Ketiga. 
Kuala Lumpur: Akademi Pengajian Melayu, Universiti Malaya, 2001.

Hawwā, Sa`ìd. Al-Mustakhliṣ fī Tazkiyah al-Anfus. Beirut:

Dār Ammār, t.t.

Hawwa, Sa`id. Tarbiyyah al-Ruhaniyyah, terj. Khairul Rafie. Bandung: Pustaka Mizan, 1988.

Ibn Manzūr, Jamāl al-Dīn Ibn Muḥammad Ibn Makram. Lisān al- 'Arab, jil. 16. Beirut: Dār Șādir, t.t.

Ishamuddin Abd. Rahim. "Tokoh Ulamak al-Syeikh Abd al-Qadir al-Mandili: Tinjauan Pemikirannya dari Aspek Politik." Latihan Ilmiah Sarjana Muda Pengajian Islam, Universiti Kebangsaan Malaysia, 1987.

Al-Jurjānī. Al-Ta rî̉fāt. t.tp: Dār al-Kutub al-'Ilmiyyah, 2000.

Karzon, Anas Ahmad. Tazkiyatun Nafs: Gelombang Energi Penyucian Jiwa Menurut al-Qur'an dan asSunnah di atas Manhaj Salafus Shaalih, terj. H. Emiel Threeska. Jakarta: Penerbit Akbar Media Eka Sarana, 2010.

M. Solihin. Penyucian Jiwa dalam Perspektif Tasawuf alGhazali. Bandung: CV Pustaka Setia, 2000.

Al-Mandili, ' Abdul Qadir bin Abd. Mutallib al-Indunisi. al-Madhhab atau Tiada Haram Bermazhab. Mesir: Maṭba ah al-Anwār, $1379 \mathrm{H}$.

Al-Mandili, ' Abdul Qadir bin Abd. Mutallib al-Indunisi. Senjata Tok Haji dan Tok Lebai. Thailand: Mațba`ah Bin Halabi, t.t.

Al-Mandili, 'Abd Qadir bin 'Abd. al-Mutallib al-Indunisi. Sinar Matahari Buat Penyuluh Kesilapan Abu Bakar alAsy'ari. Mesir: Maṭba`ah al-Anwār, 1379H.

Al-Mandili, 'Abdul Qadir bin 'Abd. al-Mutallib alIndunisi. Pembantu Sekalian Orang Islam dengan Harus Membaca Qur'an dan Sampai Pahalanya Pada Sekalian Yang Mati. Pulau Pinang: The United Press, 1962. 
Al-Mandili, 'Abdul Qadir bin 'Abd. al-Mutallib alIndunisi. Penawar Bagi Hati. Pattani: Matba'ah Bin Halabi, t.t.

Al-Mandili, 'Abdul Qadir bin Abd. Mutallib al-Indunisi. Anak Kunci Syurga, cet. ke-2. Pulau Pinang: The United Press, t.t.

Al-Mandili, 'Abdul Qadir bin Abd. Mutallib al-Indunisi. Beberapa Mutiara yang Bagus Lagi Indah atau Beberapa Masalah yang Penting Lagi Mudah. Mesir: Mațba ah al-Anwār, $1380 \mathrm{H}$.

Al-Mandili, 'Abdul Qadir bin Abd. Mutallib al-Indunisi. Islam Agama dan Kedaulatan. Mesir: Mațba`ah alAnwār, 1379H.

Al-Mandili, 'Abdul Qadir bin Abd. Mutallib al-Indunisi. Menakutkan dan Meliarkan daripada Memasukkan Orang-orang Islam akan Anak-anak Mereka Itu ke dalam Sekolah Orang Kafir. Mesir: Maṭba`ah alAnwār, $1380 \mathrm{H}$.

Mohamad Abu Bakar. "Tanah Melayu Abad ke-19: Pengislaman, Penjajahan dan Pemupukan Manhaj Melayu." Dalam Islam di Tanah Melayu Abad ke-19, ed. Farid Mat Zain. Shah Alam: Karisma Publications Sdn. Bhd, 2007.

Mohammed Bazri Che Harun. "Hadith-hadith dalam Karya Syeikh 'Abd. al-Qadir al-Mandili: Takhrij dan Analisis." Disertasi Sarjana Usuluddin, Universiti Malaya, 2012.

Mohd Sulaiman Yasin. Akhlak dan Tasawuf. Bangi: Yayasan Salman, 1992.

Othman Hj. Mohamed. Prinsip Psikoterapi dan Pengurusan Dalam Kaunseling, edisi ke-2. Serdang: Penerbit Universiti Putra Malaysia, 2005.

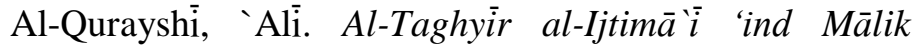
Bennabì. Kaherah: al-Zahra li al-I’ lām, 1989. 
Al-Rāghib Al-Isfahānī, al-Ḥusayn bin Muhammad. Mufradāt fì Gharib al-Qur'ān. Beirut: Dār Ihỵā' alTurāth al-`Arabì, 2002.

Ramli Awang. Syeikh Abdul Qadir al-Mandili (19101965): Biografi \& Pendidikan Akhlak. Skudai: Penerbit Universiti Teknologi Malaysia, 2008.

Rosihan Anwar dan Mukhtar Solihin. Ilmu Tasawuf. Bandung: Pustaka Setia, 2004.

Sapora Sipon dan Ruhaya Hussin. Teori Kaunseling dan Psikoterapi, ed. ke-3. Nilai: Penerbit Universiti Sains Islam Malaysia, 2012.

Sayyid Qutb. Tafsir Fi Zilalil Qur'an: Di Bawah Bayangan Al-Qur'an, j.8, terj. Yusoff Zaky Haji Yacob. Kota Bharu, Kelantan: Pustaka Aman Press, 2000.

Sharifah Basirah Syed Muhsin. "Kaedah Psikoterapi Berasaskan Konsep Maqamat: Kajian Terhadap Kitab Qut Al-Qulub Abu Talib Al-Makki.” Disertasi Sarjana Usuluddin, Universiti Malaya, 2012.

Shukri Ahmad. Pengaruh Pemikiran Ulama di Semenanjung Malaysia Akhir Abad ke-20. Sintok: Penerbit Universiti Utara Malaysia Sintok, 2011.

Al-Suyuti, Jalal al-Din Muḥamad al-Maḥalli. Tafsir Jalalain, j.2, terj. Najib Junaidi. Surabaya: PT. eLBA Fitrah Mandiri Sejahtera, 2010.

Al-Taftazani, Abu al-Wafa' al-Ghanimi. Perkembangan Tasawuf Islam, terj. Abdul Shukor Haji Husin dan Mudasir Rosder. Kuala Lumpur: Bahagian Hal Ehwal Islam, Jabatan Perdana Menteri, 1996.

Tugby, Donald John. Cultural Change and Identity Mandailing Immigrants in West Malaysia. St. Lucia: University of Queensland, 1977.

Usman Pelly. Urbanisasi dan Adaptasi Peranan Misi Budaya Minangkabau dan Mandailing, ed. Taufik Abdullah. Jakarta: LP3ES, 1994. 
Usman Shihab, "Agama dan Perubahan Masyarakat Menurut Malik Bennabi," Jurnal Akidah dan Pemikiran Islam AFKAR, Bil. 10 (Mac 2009).

Zakaria Stapa. Akidah dan Tasawuf. Kuala Lumpur: Bahagian Hal Ehwal Islam Jabatan Perdana Menteri, 1997.

\section{TEMUBUAL}

Syeikh Muhammad Husni Ginting (Mudir Pesantrean Husniyyah,Langkat) dalam temubual dengan pengkaji pada 20 November 2013.

Tuan Guru Khairul Anwar Syafie (Mudir Pondok Pengajian Darul Muhajirin, Gajah Teriak, Jitra) dalam temubual bersama penulis, 15 September 2012.

Temubual dengan Tuan Guru Abd. Raof al-Bahanji, (Mudir Pondok Tampin) bersama pengkaji pada 21 November 2013.

Temubual dengan En. Mahfor bin $\mathrm{Hj}$. Hassan, cucu kepada Tuan Guru Ismail Che' Dol pada 6 Oktober 2012 di Kampung Batu Hampar, Pendang Kedah. 
Che Zarrina \& Nor Azlinah, "Terapi Spiritual melalui Kaedah Tazkiyah alNafs," Afkār Vol. 18 Special Issue (2016): 35-72 